\title{
Token Economy to Improve Concentration among Students with Learning Disabilities in Primary School
}

\author{
Noor Azreena A Aziz ${ }^{\text {a }}$ Mohd Hanafi Mohd Yasin ${ }^{\mathrm{b}}$ \\ aSekolah Kebangsaan Keru, 73000 Tampin, Negeri Sembilan, Malaysia \\ ${ }^{b}$ Universiti Kebangsaan Malaysia, 43600 Bangi, Selangor, Malaysia \\ E-mail: azryna90@gmail.com
}

\begin{abstract}
This study aimed to increase student's concentration on learning and facilitating process in the classroom. A student from the Special Education Integration Program. was selected as the respondent of this study. The token economy approach had been implemented in this study to solve respondent behavioural problem who was not paying attention when completing classroom task. This study employed a qualitative, A-B-A single subject design which A and B represented baseline and intervention phase respectively. Observation was carried out in three different phase, namely baseline ( 2 weeks), intervention ( 2 weeks) and no intervention ( 2 weeks). Total duration of this study was 6 weeks. During early observation, to be found that interruption from other classes had caused distraction to respondent in completing the task given. Therefore, token economy was used to enhance students' motivation in paying attention and completing the task correctly. Token is given when respondent managed to answer questions correctly and neatly, and did not exhibit any disruptive behaviour within the stipulated period. Then, token was redeemed for tangible reinforcement according to the total scores of token. The results indicate that respondent had succesfully paying attention during completion of task.
\end{abstract}

Keywords: Token economy, Concentration, Disruptive behaviour, Students with learning disability

Children diagnosed with developmental disability, autism, mental retarded or those who have intellectual disability often display negative behaviour in and out of school. These condition caused them to have difficulties in learning or problems meeting the expectations of schools (Zlomke \& Zlomke, 2003). Therefore, behavioural management of students with special needs is the utmost challenge for special needs' teachers in guiding and educating the group. Disruptive behaviours displayed by students will be more complex if the undesired behaviours are not being addressed during the early stage and in consistent. (Noor \& Norhafizah, 2015). Behaviour is an action or conduct of a student in responding to and exploring new things in his environment. (Zalina, Yasin \& Tahar, 2016). Often, the behaviour can be measured and observed by other people in the surrounding. According to Deshmukh (2016), behaviour is divided into two category, namely adaptive behavior dan maladaptive behavior.

Adaptive behavior refers to the degree or ability of an individual in meeting the standard and responsibility towards oneself and society. Among the bahavioural aspects of adaptive behaviour are: language; activities of daily living; reading and writing; time and number concepts; domestic and social; and pre-vocational. An individual's ability to conduct himself will be seen as influenced by the environment of his experience.
In contrast, maladaptive behavior is not an ageappropriate behaviour, not accepted by society, harmful to oneself and interruptive in the process of learning. The examples of maladaptive behavior are aggressive and destructive behaviour, rampage, react negatively to others, self-harm, peculiar and repetitive.

Therefore, behaviour modification is seen as a method to teach a person new behaviour or change the existing behaviour through positive or negative reinforcement (Kappel et al., 2012). There are various technique of behaviour modification that can be used to reduce the occurrence of undesired behaviour to an appropriate and acceptable behaviour. Skinner believes that positive reinforcement is more effective than punishment during the process of changing and maintaining deisred behaviour (Adibsereshki et al., 2015). It is evidenced in past studies that behaviour modification techniques like positive reinforcement, token economy and response cost are able to decrease the likelihood of children disruptive behaviour to happen in the classroom (Baker \& Allen, 2011; Carnett et al., 2014; Didden et al., 1997; Doll et al., 2013; Filcheck et al., 2004; Hirst et al., 2016; Tarbox et al., 2006).

Many studies make an association of positive reinforcement with academic achievement and 
concentration in classroom. Adibsereshki et al. (2015) has conducted a study to determine the relationship between classroom reinforcement with academic achievement of students with intellectual disabilities. 45 students in Tehran were the respondents of this study. As a result, the group that received positive reinforcement shows higher achievement in Science in comparison with the control group that received no reinforcement.

One of the famous techniques used to provide positive reinforcement is token economy. Doll, McLaughlin and Baretto (2013) have defined token economy as an effective method in behaviour management, not only in school but also shows an effect in the environment of community, prison, army organisation and psychatric hospital. Fiksdal (2015) says in his study that the use of token economy is more effective in reducing disruptive behaviour compared to the punishment.

A token economy is an intervention that includes contingencies in which tokens or points are given following the emission of targeted behaviors (Adibsereshki et al., 2015; Carnett et al., 2014; Fiksdal., 2015; Hirst et al., 2016; Robacker et al., 2016; Zlomke \& Zlomke, 2003). Contingency in this context refers to the plans designed to deal with things or events that are expected to occur in the future (Kamus Dewan Edisi Keempat). This situation clearly demonstrates that token economy is used to reduce negative behaviours or reinforce the positive behaviours expected to occur at a time or situation in the future.

Tokens can be redeemed for reinforcing objects or activities at a later point in time. The objects or activities have to be something of students' favour and interest. Adibsereshki et al. (2015) divides reinforcement into two categories, namely tangible and social reinforcement. Tangible reinforcement is provided in the form of an object, while social reinforcement is given to students in the form of praise and activity when desired behaviour is exhibited. Students with special needs are more suitable to be rewarded with physical token as it can be seen and interpreted easily. (Doll, McLaughlin and Baretto, 2013).

Carnett et al. (2014) had used a token economy for a student with autism to increase student's concentration during reading activity. While, McLaughlin and Malaby (1972) had used token economy to increase students' intrinsic motivation on completion of task. Concentration and intrinsic motivation in completing a task is known as on-task behaviour. A child should acquire the skills to work independently and follow teacher's instructions and have an eye contact with the teacher during the activity. A positive improvement of on-task behaviour will enhance academic performance and reduce undesired behaviour as well as smoothen the current process of learning (Clare et al., 2000).
The purpose of this study is to examine the effects of token economy procedures in improving concentration of students with learning disabilities during independent completion of task as well as reducing disruptive classroom behaviours. However, this modification did not involve response cost system but object reinforcement was used. Additionally, praise will be complimentary to the token.

\section{METHOD}

This study used observation form for data collection on the frequency of participant's behaviour throughout 6 weeks duration. The forms were filled up by pupils personal assistant (PPA) as teacher was always preoccupied with teaching responsibilities. Therefore, a detail explanation was given to PPA by the teacher prior to the investigation. The 30 minutes allocated for the observation were timed using a stopwatch.

The respondent in this study was an 11-year-old male student who attended a primary school. He was diagnosed by doctor to have an intellectual disability when he was 8 years-old. Negative behaviours like negligent and do not pay attention as well as disturbing friends when completing independent task were exhibited during Malay Language learning session. Previously, the student was good in reading, writing and spelling, but frequently make mistake and being negligent on task completion since end of last year. The main cause of the problem was the participant did not receive full attention from the teacher when completing the task. The teacher had to give attention to other students who are weak in language skills in the same class. Besides, students' attention was affected due to the absence of partition wall between the two classes.

This study was carried out in a classroom environment of Special Education Integration Program in Keru Primary School. 4 students with learning disabilities including the respondent will follow Malay language classes for two times a week. The time allocated is one hour. Therefore, the total duration for Malay language is 2 hours per week. Besides, respondent is the only student in his class that follows Year $5 \mathrm{KSSR}$ curriculum and the rest of the students are still following Year 4 KSSR curriculum. Therefore, the respondent has to be assigned with independent task while teacher is giving attention to other students.

The research design employed in this study was an A-B-A single subject design. The duration of this research is six weeks. The first two weeks were allocated for baseline (A), two weeks for intervention (B) and the last two weeks were allocated for procedures without intervention (A). 
Table 1. Tangible Reward \& Total of Redeemed Token

\begin{tabular}{lccc}
\hline \multicolumn{1}{c}{ Item } & $\begin{array}{c}\text { Total Of } \\
\text { Redeemed } \\
\text { Token }\end{array}$ & Item & $\begin{array}{c}\text { Total Of } \\
\text { Redeemed } \\
\text { Token }\end{array}$ \\
\hline Mini Fan & 30 & Chocolate & 10 \\
Cereals & 30 & Mechanical & 10 \\
(Koko & 30 & Pencil & 10 \\
Krunch) & 30 & Triangular & 9 \\
Cereals & 25 & Pencil & 6 \\
(Honey & 20 & Glue (big) & 5 \\
Star) & 20 & Glue & 3 \\
Cereals & 15 & (small) & 3 \\
(Cornflakes) & 15 & Balloon & 2 \\
Coin Box & & Eraser & \\
Colour & & Ruler & \\
Pencil & & & \\
Pen & & & \\
Note Book & & & \\
+ Mini Pen & & & \\
Wafer Rolls & & Pencil & \\
\hline
\end{tabular}

Data was collected in 5 observations of two times per week during the last 30 minutes of each class. This specific duration is chosen as student will start to complete the task independently after going through the teaching and facilitating process.

This study starts with a face-to-face discussion between teacher and respondent. Further explanation on the token has been given. Respondent clearly understand about the desired behaviour that is, paying attention to independently complete the task correctly and neatly. Ten token of coloured stickers will be given if student succesfully exhibited target behaviour that is to pay attention in completing the task given. There is no token will be given away if student conducts disruptive behaviour like disturbing friends and contemplating. The token is pasted on token economy chart, so that respondent could check their self-performance independently.

In improving the effectivenes of token economy application, respondents has been shown a basket of various tangible reinforcement. Table 1 shows respondent has arranged the tangible reinforcement in order according to the selection of interest. The number of token for redeemed will be determined by other teachers. Each reinforcement is arranged and labeled according to priority and will be placed in the classroom to reinforce respondent in establishing target behaviours.

\section{Baseline (A)}

At this stage, there is no token economy implemented on the respondent. Teacher controls respondent behaviour as usual. Any disruptive behaviours (disturbing friends, contemplating) will be given warning by the teacher. Additionally, teacher has to give full attention to the respondent individually when he is completing the task given. Baseline data is collected using the observation form for 2 weeks, on every Monday and Thursday during Malay language period. The time taken will be the last 30 minutes of Malay language period and after 30 minutes of learning on the beginning. There is no positive reinforcement (praise) will be given during this baseline stage.

\section{Token Economy/Intervention (B)}

Token economy in the form of small round sticker will be used over two weeks. The sticker will be given to the respondent at the end of the class session. Respondent is responsible to stick the sticker that was obtained from the reward chart board. The list of rewards and the amount of token were pasted in front of the class.

Respondent is given a chance to get a maximum of 10 token in 30 minutes for every Malay Language period (Monday, Thursday). Token will be given if the respondent exhibits attention on the completion of task given. Five tokens are allocated for the target behaviour that is paying attention, while another 5 tokens will be given if the respondent able to independently complete the task correctly and neatly. Token will not be taken back (response cost) if respondent does not able to complete the task and disturbing friends as well as contemplating. Respondents will be given reminder and warning that no token will be given in certain condition.

\section{Baseline/ No Intervention (A)}

On the fifth and sixth week (final stage), no intervention (token economy) was implemented to respondent. Respondent behaviours were observed similar to baseline procedure (A) for two weeks in the early stage of this study.

\section{FINDING AND DISCUSSIN}

\section{Findings}

Graph 1 displays the frequency of respondent exhibiting disruptive behaviours on daily basis (Monday, Thursday) during baseline phase. The highest frequency of disruptive behaviours was recorded on the first week, that is 18 times of occurrence with 16 mistakes were made on the task given. Respondent was still in negligence and did not pay attention in the class as well as completing the task perfunctorily. 


\section{Graph 1. The frequency analysis results on respondent behaviours}

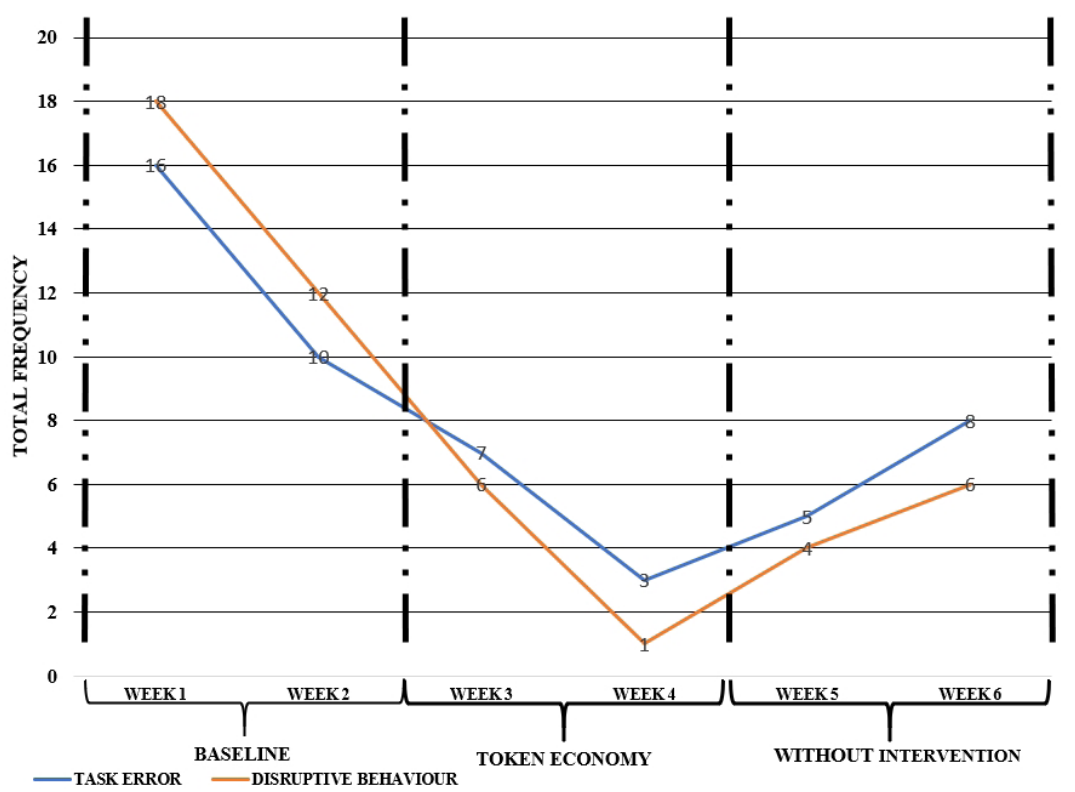

On the third and fourth week, respondent started to exhibit changes in behaviour and able to complete the tasks independently. The implementation of token economy was applied on the respondent. Errors in tasks show a decline to 3 on the fourth week. On the other hand, disruptive behaviours had succesfully decline to 1 times. This clearly demonstrates that the application of token economy had successfully established target behaviours in 2 weeks duration.

Nevertheless, the total frequency of errors and disruptive behaviors increase again on the fifth and sixth weeks. The absence of token economy intervention had caused a decline in respondent's motivation. Respondent made 5 errors in the assignment and 4 times of disruptive behaviours. The total frequencies increased in the sixth week that is 8 errors in the assignment and 6 times of disruptive behavior. This increment portrays the importance of continuous intervention until respondent can really be self-reliant in completing the task and disruptive behavior is eliminated.

\section{Discussion}

The results of this study replicate previous research on the effectiveness of token economies in enhancing students' concentration during completion of tasks. Tangible reinforcement of interest has attracted respondent to cooperate in helping himself to behave. In addition, social reinforcement also was given to the student as an appreciation to the task completed.

Behavioural problem will continue to happen regardless of teachers' leadership styles or any discipline that exist. This is due to the students that come from range of background, personality, intellectual, physical, social and socio-emotions (Mok, 2009). In addition, special needs students need more encouragement and attention than tipical students, so that they will pay more attention in the classroom and complete the tasks given (Zecker, 2006).

Token economy has played an important role in behaviour modification particularly in education field. The method of giving reward to individuals for maintaining, eliminating or improving positive behaviours has been accepted and practiced by many parties other than school. It is a secondary needs like appreciation of life in psychological context towards bringing about happy and positive emotions in conducting activity (Suppiah, Ramlah, \& Abdul, 2008).

\section{CONCLUSSION AND SUGGESTION}

\section{Conclussion}

Token economy has played an important role in behaviour modification particularly in education field. The method of giving reward to individuals for maintaining, eliminating or improving positive behaviours has been accepted and practiced by many parties other than school. The modification technique chosen is not a matter, but the right implementation steps and methods have to be complied. This compliance will assure the effectiveness of procedure as well as assisting children with special needs to control selfbehaviour. The most important thing is to not give up as 
each and every child has individual needs and various methods have to be conducted in order to achieve the mission. One method that works for an individual is not necessorily worked on others.

\section{Suggestion}

To ensure students' concentration during complementation of task, it is needed attention and reinforncement from teacher. It is also needed the various methods to be conducted in order to get more effective result.

\section{REFERENCES}

Adibsereshki, N., Abkenar, S. J., Ashoori, M., \& Mirzamani, M. (2015) The effectiveness of using reinforcements in the classroom on the academic achievement student with intelectual disabilities. Journal of Intellectual Disabilities, 19(1), 83-93.

Carnett, A., Raulstun, T., Lang, R., Tostanoski, A., Lee, A., Sigafoos, J. \& Machalick, W. (2014) Effects of a perseverative interest-based token economy on challenging and on-task behavior in a child with autism. Journal Of Behavioral Education, 23(1), 368-377.

Clare, S. K., Jenson, W. R., Kehle, T. J. \& Bray, M. A. (2000) Self-modeling as a treatment for increasing on-task behavior. Psychology in te schools, 37(6), 517-522.

Deshmukh, D. V. (2016) Strategies used to modify the hehaviors of children with intellectual disability. Indian Journal Of Health And Wellbeing, 7(7), 753-756.

Didden, R., De Moor, J., \& Bruyns, W. (1997). Effectiveness of DRO tokens in decreasing disruptive behavior in the classroom with five multiply handicapped children. Behavioral Interventions, 12(2), 65-75.

Doll, C., McLaughlin, T.F., \& Bareetto, A. (2013) The token economy: a recent review and evaluation. International Journal of Basic and Applied Science, 2(1), 131-149.

Filcheck, H., McNeil, C., Greco, L., \& Bernard, R. (2004). Using a whole-class token economy and coaching of teacher skills in a preschool classroom to manage disruptive behavior. Psychology in the Schools, 41(3), 351-361.

Fiksdal, B. L., (2015) A comparison of the effectiveness of a token economy system, a response cost condition, and a combination condition in reducing problem behaviors and increasing student academic engagement and performance in two first grade classrooms. Theses, Dissertations, and Other Capstone Projects. Paper 343.
Hirst, E. S. J., Dozier, C. L., \& Payne, S. W., (2016) Efficacy of and preference for reinforcement and response cost in token economies. Journal of Applied Behavior Analysis, 49(2), 329-345.

Kappel, B., Dufresne, D. \& Mayer, M. (2012) From behavior management to positive behavioral support. Laporan. Department of Health and Human services, Administration on Developmental Disabilities.

McLaughlin, T. F. \& Malaby, J. E. (1972) Intrinsic reinforcers in a classroom token economy. Journal of Applied Behavior Analysis, 5(1), 263-270.

Mok, S. S. (2009) Masalah disiplin dan tingkah laku bermasalah bilik darjah. Dlm. Mok Soon Sang (pnyt). Siri Pengajian Profesional: Pengurusan Bilik Darjah Dan Tingkah Laku, hlm. 244-259. Puchong: Penerbitan Multimedia Sdn. Bhd.

Noor, A. A., \& Norhafizah, A. H. (2015) Tahap pengetahuan guru Pendidikan khas apabila mengurus tingkah laku murid bermasalah pembelajaran. Asia Pacific Journal Of Educators And Education, 30(1), 73-88.

Robacker, C. M., Rivera, C. J., Warren, S. H., (2016) A token economy made easy through Class Dojo. Intervention in School and Clinic, 1-5.

Suppiah, N., Ramlah, J., \& Abdul, A. A. S., (2008) Motivasi dalam pengajaran dan pembelajaran. Dlm. Suppiah Nachiappan, Ramlah Jantan \& Abdul Aziz Abdul Shukor (pnyt). Siri Pendidikan Guru. Psikologi Pendidikan, 242-243. Shah Alam: Oxford Fajar Sdn. Bhd.

Tarbox, R., Ghezzi, P., \& Wilson, G. (2006). The effects of token reinforcement on attending in a young child with autism. Behavioral Interventions, 21(3), 155-164.

Zalina, K., Yasin, M. H. M., \& Tahar, M. M. (2016) Penggunaan peneguhan positif: pujian dan token ekonomi untuk modifikasi tingkah laku murid pendidikan khas 'slowlearner'.https://www.researchgate.net/ publication/311105655_Penggunaan_Peneguhan_ Positif_Pujian_dan_Token_Ekonomi_untuk_ Modifikasi_Tingkahlaku_Murid_Pendidikan Khas_Slow_Learner $\{8$ April $201 \overline{7}\}$.

Zecker, S. 2006. Underachievement and learning disabilities in children who are gifted. (Online) (http://www.Ldaor.org/NewsletterFall2005.html/) accessed 4 April 2017.

Zlomke, K., \& Zlomke, L. (2003). Token Economy Plus Self-Monitoring to Reduce Disruptive Classroom Behaviors. Behavior Analyst Today, 4(2), 177-182. 